\title{
MICHELE SAVONAROLA AND THE FERA OR BLIGHTED TWIN PHENOMENON
}

\section{YNEZ VIOLÉ O'NEILL*}

QUATTROCENTO medical writings have fascinated few modern historians of medicine. Despite Lynn Thorndike's masterful challenges to it, ${ }^{1}$ George Sarton's view has generally prevailed with investigators, that for science the Italian Renaissance, while perhaps a period of preparation, was certainly a period of dissolution. ${ }^{2}$ Although in recent years historians have come to realize that Vesalius' achievement was built on a tradition of anatomical investigation that developed in the Italian universities during the fourteenth and fifteenth centuries, ${ }^{3}$ they have disregarded in large part the clinical writings of the academicians who lectured on medical topics in the same institutions. Historians of embryology and generation in particular seem to have ignored the works of the physicians whose interests led them to consider these subjects during the period between the lives of Mondino and Leonardo da Vinci, ${ }^{4}$ and in consequence, have overlooked a curious but significant account almost hidden in a medical encyclopaedia compiled by Giovanni Michele Savonarola.

The purpose of this paper is to present Savonarola's description of an obstetrical rarity, to examine his explanation of it in light of the sources he believed to be authoritative, and to demonstrate how it and certain other obstetrical phenomena not only may be elucidated by modern findings, but may illuminate the medical thought of his age. Since the account is contained in Savonarola's Practica major, ${ }^{5}$ it seems appropriate to review briefly some of the facts known concerning the life and writings of that distinguished but ever genial student of human nature. ${ }^{6}$

Overshadowed by the dramatic and tempestuous events in the career of his grandson Girolamo, Michele Savonarola's medical works and accomplishments are generally neglected. ${ }^{7}$ He deserves better treatment. A physician and philosopher, he was an illustrious member of the intelligentsia of his time. His life, the many and diverse works that he composed, and the role that he played in the society of the Italian Renaissance place him among the most influential and enlightened personalities of Northern Italy during the middle of the fifteenth century.

Born in Padua around 1385, Savonarola died at Ferrara, some time after 1461 and perhaps as late as $1468,{ }^{8}$ having lived a life that was divided between the two cities. A student and later a professor at the University of Padua, he moved to Ferrara in his fifty-fifth year, and remained there as physician and councillor to the d'Este rulers until his death.

*Assistant Professor, Department of Anatomy, Medical History Division, University of California, Los Angeles. This publication was supported in part by NIH Grant 1 RO 1 LM 01941-01 from the National Library of Medicine.

Medical History, 1974, vol. 18. 


\section{Michele Savonarola and the blighted twin phenomenon}

As his prince and patron Lionello d'Este proclaimed, ${ }^{9}$ Michele Savonarola was a prolific author. His interests ranged over a variety of subjects, and his writings reflect these myriad concerns. ${ }^{10}$ Even the medical topics he explored were diverse, including considerations of such standard subjects as fevers, the pulse, the plague, and the urine, ${ }^{11}$ as well as discussions of less frequently examined themes, as physiognomy, baths, ${ }^{12}$ and the distillation of alcohol, together with the effects of aquavitae upon the human body. ${ }^{13}$ Undoubtedly his most popular book, however, was a small manual on obstetrics and child care written in Italian shortly before 1460, and addressed as the subtitle reads, "To the women of Ferrara on the regimen of pregnant women and of the new born up to the age of seven years". ${ }^{14}$ Though designed for the lay reader, the small volume contains a wealth of learning and experience, for the phenomenon of human generation had long piqued the curiousity of its author.

Illustrative of an incipient state in the development of his interest in the subject are two chapters of the sixth treatise in Savonarola's first major medical work. Designed as a commentary on the Canon of Avicenna and titled Practica major, this medical compendium was completed, very likely, in 1440 , a few months prior to Savonarola's transfer from Padua to Ferrara at the insistence of the d'Este princes. ${ }^{15}$ The most extensive section of that work, the sixth treatise, contains brief accounts of the ailments that afflict the human body. Having arranged his discourse on these morbid processes in the traditional de capite ad pedes order, Savonarola considered the anatomy, physiology and pathology of the male genito-urinary tract towards the end of the treatise, in the twentieth chapter, and then turned in the next section to discuss comparably the female members and their role in human generation. ${ }^{16}$ Appended to the exposition on obstetrics in that chapter are several rubrics dealing with certain complications of pregnancy, and included among them is one titled De mola. ${ }^{17}$

The fact that Savonarola chose to reflect upon the mola uteri in the obstetricgynaecologic chapter of the Practica is neither striking nor original. The syndrome had been described often even in classical times. A Hippocratic author, Galen, Pliny, Soranus of Ephesus, and Paul of Aegina, all had commented on the pathological condition during which a hard, fleshy object forms in the human uterus. ${ }^{18}$ Medieval medical compendia also generally contained an account of the mola uteri, and in some of these, the concept of the Frater Salernitanarum or Lombardorum recurs as a leitmotiv. Thus, Bernard of Provence tells us that Gerard of Bourges in the chapter on expulsion of the secundines in his commentary on Constantine's Viaticum mentioned that the pathological uterine formations were called Frater Salernitanarum, Frater Lombardorum, or Arpia. Early in the thirteenth century, Gilbert of Aquila (Gilbertus Anglicus) also gave an account of the same phenomena, and a century later, Bernard of Gordon explained that the large objects grew in the wombs of Lombard women owing to the fact that they either laboured too hard, or were repressed, and in the matrices of Apulian women, because, though Italians dressed well, they ate poorly. ${ }^{19}$

Of the prior descriptions of the phenomenon, however, one of the most important for Savonarola and his contemporaries would seem to have been the accounts of the mola uteri found in the biological writings attributed to Aristotle. Their influence 


\section{Y. V. O'Neill}

necessitates a summary sketch of the intricate and important history of the transmission of those accounts as well as of the writings containing them.

Some time before 869 , and probably during the first half of the ninth century, an unknown translator rendered Aristotle's chief zoological works from a Syrian text into Arabic. ${ }^{20}$ The Arabic version, known as the Kitāb al-hayāwān, is divided into nineteen books consisting of Historia animalium (10 books), De partibus animalium (4 books), and De generatione animalium (5 books). The tenth book of the Kitäb al-hayāwān, generally considered by most modern authorities to be spurious, ${ }^{21}$ was accepted as genuine by medieval Islamic scholars, and in particular by Avicenna, who has been universally regarded as one of Aristotle's chief exponents. ${ }^{22}$ In consequence, the Persian physician and others were forced into a dilemma.

In De generatione animalium, and predicated upon his doctrine of universal causation, Aristotle developed his famous theory of generation in which he maintained that the male supplies the form and the female the matter of the embryo. ${ }^{23}$ The author of the tenth book of Historia animalium, however, expounded a theory that not only differed from, but contradicted the Aristotelian teachings on this subject. The theory propagated in the spurious work is that the female, like the male, contributes semen to the process of generation, and that a seminal discharge of the female is essential for procreation. ${ }^{24}$

Oddly, both theoreticians sought the demonstration of their doctrines in the example of the mola uteri, and therefore, two accounts of the syndrome appear in the Kitäb al-hayāwān. ${ }^{25}$ The syntax and vocabulary are similar in both descriptions, causing the inference to be drawn by some that Aristotle must have composed at least this part of the spurious work. ${ }^{26}$ Recently, a scholar has reversed this line of reasoning and suggested that the section in question may have been copied from the genuine account, the description of the syndrome in De generatione animalium serving as the prototype for the parallel passage in the tenth book of Historia animalium. ${ }^{27}$ In any event, the two accounts were rendered into Latin from the Kitäb al-hayāwän during the first quarter, and perhaps as early as the first decade of the thirteenth century by Michael Scot, who titled his version, Liber de animalibus. ${ }^{28}$

Some years later, Michael Scot translated Avicenna's succinct commentary on the Kitäb al-hayāwän, and this compendium, also divided into nineteen books, is known in Latin as Abbreviatio Avicenne de animalibus. ${ }^{29} \mathrm{Just}$ as in the Arabic and Latin versions of the Aristotelian writing upon which it was modelled, the Abbreviatio contains two descriptions of the mola uteri, and two widely divergent and conflicting theories concerning the etiology of the syndrome and the nature of the female component in generation. ${ }^{30}$ Given this confusing situation, and the fact that he was aware, very likely, of other authoritative but contradictive explanations of generation and of the pathogenesis of the mola uteri ${ }^{31}$ it is scarcely surprising that Savonarola, like several of his Quattrocento colleagues, sought to widen the theme by showing that the uterine mass might result from any of a number of pathological conditions..$^{32}$

Thus he held that one type of mola might occur as the result of tumorigenesis. ${ }^{23}$ The other three causes for the phenomenon that Savonarola listed had been borrowed from Avicenna. The Persian physician had maintained in the Canon that the fleshy mass formed in the uterus owing either to excess heat in the matrix, or to a defect in 


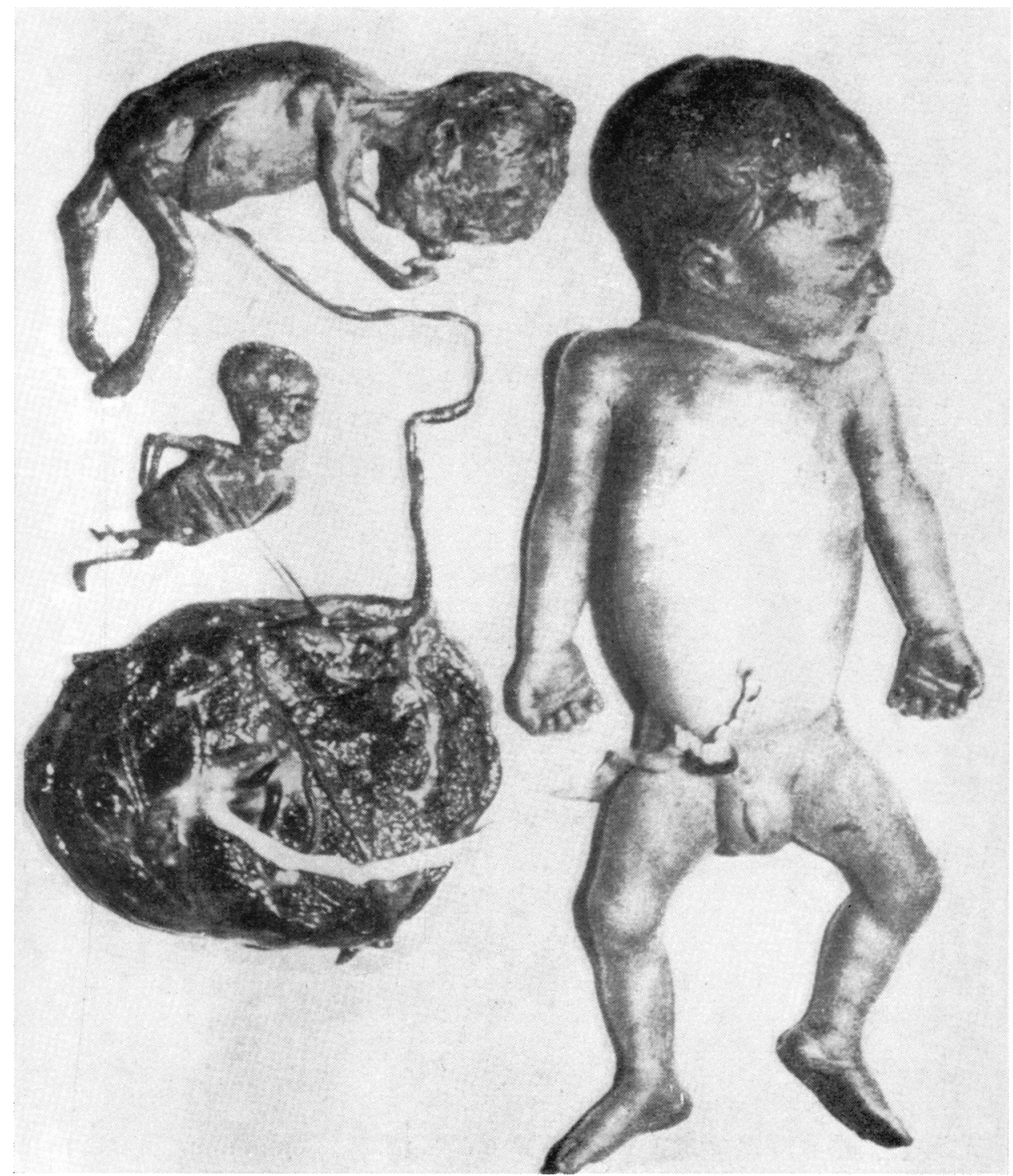

The Sardinian triplets (see p. 230). From A. Esposito, 'Singolare caso di gravidanza trigemina con due feti mummificati', Clin. Ostet. Ginec., 1963, 65: 539, Fig. 1. 


\title{
Michele Savonarola and the blighted twin phenomenon
}

the male component of generation. ${ }^{34}$ In the tenth book of the Abbreviatio, however, Avicenna, drawing on the theory of generation posited by the author of that work, explained that the mola uteri occurred when the female seed was retained in the uterus, and an unusually strong heat arose there. The intra-uterine calorification prevented the entry of the male semen to the womb, and subsequently baked the female seed remaining there into a dense mass. ${ }^{35}$

While repeating these theories, and citing the source of the last one listed, ${ }^{38}$ Savonarola seems to have ignored the explanation for the phenomenon set forth by Aristotle in the eighteenth book of his de animalibus. Aristotle, having rejected the concept of female semen, and having contended that generation occurred only when the male dynamic principle imposed form on the female plastic element, refused to assign the cause of the mola uteri to a defect in the formal cause, but explained that the pathological phenomenon resulted from the inability of the matrix to supply sufficient heat to effect the coction necessary for the normal formation of an embryo. ${ }^{87}$ The omission of this theory by Savonarola seems particularly odd because in the next sentences of his mola discussion, the Paduan practitioner referred to the eighteenth book of Aristotle's de animalibus, and seems to have been influenced by the Aristotelian doctrine of generation in his explanation of a strange human phenomenon.

Having commented upon the indurate qualities of the discharged mola, Savonarola paused, as if to justify the details and direction of his narrative, and made the following significant observation:

\begin{abstract}
And this happens, although our women may believe it to be impossible, still it is a fact. Even in our city such things have taken place, and my mother, who was a trustworthy woman had seen them. Among women of warm climates and southern regions, or among women who have much and defective blood resulting from an imperfect regimen, it sometimes happens that in addition to one truly conceived foetus, a piece of flesh bearing the form of a living animal is brought forth. The women call that thing a fera, which is not caused by the power [virtue] of the first sperm of the man, for from it the foetus has already been conceived, but by an error of the second sperm, that was sent forth in the second coitus. Its defect proceeds from the influence of the constellations or the virtues of the heavens as Aristotle relates in the eighteenth book of de animalibus. Similarly, in certain parts of Apulia, as my father observed, 28 women are delivered of a foetus, and at the same time of a fera which may resemble an owl, hawk, eagle, lizard, or other similar things. The women maintain that when with that foetus, the beast comes forth as a noble fera, or as a hawk or the like, then the foetus was engendered by a distinguished person. If the fera were base, like an owl, or a lizard, and the like, then it was engendered by a rustic or a man of low station, and that fera sometimes kills the foetus. For it is said that this [lethal] property is so great that if on being brought into the world, at the hour of delivery, it [the fera] should attack the human offspring, the foetus dies instantly."9 These things are true but may not seem so, for we are not accustomed to seeing such things here. ${ }^{.0}$
\end{abstract}

Several of Savonarola's preconceptions concerning human generation emerge in this passage. Although his belief that the father supplied the form of the foetus can be traced to Aristotle, his attribution of the fera phenomenon to a masculine flaw represents a departure from the Aristotelian doctrines on the subject. His further assigning of its etiology to celestial influences not only reveals the astrological prejudices of the era in which he lived, ${ }^{41}$ but demonstrates that on occasion he either misread or misinterpreted his sources.

At the conclusion of the eighteenth book of his de animalibus, Aristotle stated that 


\section{Y.V. O'Neill}

the life spans and gestation periods of animals were governed by cosmic forces, ${ }^{42}$ but he did not account for the mola uteri syndrome or for monstrous births by linking their occurrence to astrologic or astronomic events. ${ }^{43}$ Similarly, no hint of celestial causation appears in the account of the mola in the tenth or spurious book of Aristotle's zoology ${ }^{44}$ nor in the eighteenth book of Avicenna's Abbreviatio where the mola uteri is explained as resulting from a humoral imbalance. ${ }^{45}$

It may be noted also that if, as Savonarola reported, the women of Apulia ascribed the imperfections of the fera to the social status of the creature's father, then the folklore of that region differed markedly from that in nearby Sicily. There, the features of an individual were determined by and traced to the maternal line, and hence the physical characteristics of the dame, human or animal, were scrupulously examined before marriage or conception. ${ }^{46}$ Moreover, in his acceptance of the assignment of the fault in the pathological occurrence to the genitor, it is evident that Savonarola tended to prefer the generative doctrines of Avicenna to those of Aristotle.

A similar bias is manifest in Savonarola's notions concerning human superimpregnation. Clearly demonstrated in the fera account is his belief in the possibility of the fecundation of a woman already pregnant, but previously in the Practica major, Savonarola had discussed the subject at greater length. His views on the topic appear in an earlier rubric of the same chapter as the fera account. ${ }^{47}$ In that discussion, Savonarola adhered to the analysis of superimpregnation that he found in the Canon, repeated several of Avicenna's statements verbatim, ${ }^{48}$ and seemingly ignored the dicta of Aristotle and of other ancient writers on the subject. ${ }^{49}$

Since the conclusions of Aristotle on superimpregnation, unlike many of his contentions concerning human generation, have been confirmed by modern findings and approximate to those of most modern embryologists, they deserve closer examination. Generally, two kinds of superimpregnation are distinguished, superfecundation and superfoetation. Superfecundation is defined currently as the impregnation of two or more ova, liberated at the same ovulation, by successive acts of coitus, and superfoetation as the presence of two foetuses of different ages, not twins, in the uterus due to the impregnation of two ova liberated in successive ovulations. ${ }^{50}$

Owing to his conviction that the human uterus closed completely during the gestation period, Aristotle maintained that human superfoetation, though perhaps not impossible, was unlikely. ${ }^{51} \mathrm{He}$ foresaw no contraindicants to superfecundation, however, believing that it could and did occur in human and even deific gestations, demonstrating that such an event explained the double parturition of Iphicles and Hercules of whom one was the son of Amphitryon and the other of Zeus. ${ }^{52}$ The majority of modern embryologists, while basing their judgements on more scientifically reputable evidence, hold similar views.

Conspicuous differences in birth dates, size, and the appearance of twins have often initiated speculations concerning the possibility of human superfoetation. ${ }^{53}$ The observation of such events may have motivated Savonarola to state, citing Avicenna as his authority, that after conception the os matricis was not sealed shut, but sometimes reopened so as to facilitate superfoetation. ${ }^{54} \mathrm{He}$ maintained, as had Avicenna, that when the phenomenon did occur, it was to women who were obese, hirsute, and whose characteristically copious menstrual discharges were caused by an 


\section{Michele Savonarola and the blighted twin phenomenon}

intense heat that developed within their wombs. This heat, in turn, attracted sperm even to the gravid uterus, resulting on rare occasions in the conception of a second foetus. Savonarola concluded by adding that both foetuses so conceived were likely to be weak..$^{55}$

Credence in the possibility of human superfoetation continued long after Savonarola's lifetime, and medical literature abounds with descriptions of births attributed to it. The case history William Harvey incorporated into the treatise on parturition that he appended to his classical study on generation affords a typical example. He tells us of a serving girl who having cohabited with her master, became pregnant, and to hide her condition, fled to London. There, she was delivered of a child in September, and having regained her health, returned home. In December, the birth of another child, conceived by superfoetation, revealed her indiscretion. ${ }^{56}$

Reports of similar cases still appear, and support for the view that the phenomenon exists in human as well as animal gestations is to be found in even the most recent articles. ${ }^{57}$ While ovarian follicles have been demonstrated to remain responsive to gonadotrophins throughout pregnancy, ${ }^{58}$ it should be remembered that the follicle stimulating hormone (FSH) is extremely low during pregnancy, and thus the stimulus requisite for the maturation of a new follicle is scant. Even more important are the classical experimental investigations proving that human cervical mucus, impermeable to sperm, forms an impervious barrier to its penetration into the gravid uterus, and these have tended to discredit the theory of human superfoetation. ${ }^{59}$ In consequence, most experts now account for the case histories describing what their authors term superfoetation as actually a retardation or an embryonic diapause in the uterine development of a less advanced twin. ${ }^{60}$

Superfecundation is a well-recognized occurrence in lower animals, ${ }^{61}$ but the fertilization of two ova within a short period, that is in an interval shorter than an ovular cycle, but not at the same coitus, is difficult to substantiate in human beings. It is probable that, in many cases, twin ova are not fertilized by semen ejaculated at the same coitus. This can be demonstrated, however, only in very exceptional circumstances, and the possibility has most often been suspected when a woman has given birth to infants of different skin colour.

Two illustrative case histories of such events are James Parsons' report in his Croonian Lecture of $1745,{ }^{62}$ and the communication written by John Archer, the Maryland practitioner who, at the University of Pennsylvania in 1768, had earned the first medical diploma awarded after a course of study in the American colonies. ${ }^{63}$ These and other similar accounts in the literature are usually somewhat tainted with sociological preconceptions. Often such cases can be explained by the application of genetic principles that may come into play, for when mixed racial strains are present in one or more parents, marked differences may be found in their offspring.

Landsteiner's fundamental discovery in 1901 that a difference between the bloods of normal individuals belonging to the same species could be demonstrated, and that human beings could be divided into groups on the basis of the isoagglutination reaction, though initially acclaimed primarily as a process for removing the chief hazards to the use of blood transfusion as a therapeutic measure, is now recognized also as heralding a new era in the scientific resolution of an individual's parentage. ${ }^{64}$ 


\section{Y. V. O'Neill}

Subsequent investigations into the mode of hereditary transmissions of the various blood groups resulted by 1945 in the formulation of the basic law that no agglutinogen, $A_{1}, A_{2}, B, M, N, P$, or a component of the complex $R h$ factor, can appear in the blood of a child unless it be present in the blood of one or both parents. ${ }^{65} \mathrm{~A}$ concomitant result of this determination was that it provided medical investigators with an invaluable tool for pursuing inquiry into the possibility of human superfecundation.

In 1958 this technique was used, for example, to test the paternity of a set of twins born at the Universitäts-Frauenklinik in Heidelberg. Though superfecundation was suspected, it could not be proved conclusively owing to the slight statistical possibility that one genitor had fathered both infants. ${ }^{66}$ Two years later, however, Döring presented a carefully documented case demonstrating on the basis of serologic analysis and anthropological comparisons that the conception of twin infants by different fathers had occurred. ${ }^{67}$ At last the occurrence of human superfecundation had been determined scientifically.

Thus, both of Aristotle's contentions concerning human superimpregnation, that superfoetation was unlikely owing to the closure of the gravid uterus to penetration by sperm, and that superfecundation could and did occur, have been established by modern medical research. The rarity of the occurrence of human superfecundation has been stressed repeatedly by reporting investigators, ${ }^{68}$ however, and therefore an attempt to explain Savonarola's account of the fera phenomenon on the basis of superfecundation seems unwarranted. Another possible explanation is that the discharged object the Apulian women observed was actually a pedunculated fibroid tumour.

The most common tumour among women, a fibroid uterine tumour, or as it is more often termed, a fibromyoma, is a benign tumour composed of both smooth and connective tissue. In theory, fibromyomas may originate in any part of the uterus, and may be single, but generally they are confined to the corpus uteri, and are multiple. During growth, these tumours assume one of three positions, submucous, intramural or interstitial, and subserous. Submucous fibromyomas may become pedunculated, and if the stem be severed, can separate from the uterine muscle. ${ }^{69}$ Had a uterine fibroid tumour formed, become pedunculated, and then split off from the uterine lining, it might have been discharged with a foetus as described in Savonarola's account.

The principal difficulty with this hypothesis, however, is the analogy that the women drew between the appearance of the expelled fera and the body of an animal. Fibromyomas are formed by the random deposition of tumour material, and therefore, although the shape of an occasional fibroid tumour might be considered by an imaginative observer to approximate that of an animal, pedunculated fibromyomas generally resemble nothing more than a mass of unformed flesh. The fact that the fera appeared to bear a likeness to living creatures, then, tends to discredit the theory that the objects the women described were discharged uterine fibroid tumours. A more likely solution to the diagnostic problem posed by Savonarola's account is that his is an early description of a rare but well-recognized obstetrical condition, that is, the parturition of a multiple gestation with one or more foetuses blighted.

The birth of a viable twin at or near term accompanied by the birth of one or more 


\section{Michele Savonarola and the blighted twin phenomenon}

blighted foetuses younger than the seventh month of gestation has been extensively studied, although the phenomenon occurs relatively infrequently. In 1918, a survey of the literature then available produced eighty-eight cases previously reported, ${ }^{70}$ and in 1944, Kindred was able to trace 150 pregnancies in which the mothers had been delivered at term of a living child and a foetus that had died within the first seven months of gestation. ${ }^{71}$ A study of the 136 cases of multiple pregnancy delivered on the Obstetrical Service of the Bellevue Hospital during a ten-year period revealed only one instance of the phenomenon, ${ }^{72}$ but an analysis of births occurring during a twelve-month period at the Birmingham Maternity Hospital disclosed eight cases of intra-uterine death of one of twin foetuses. ${ }^{78}$

Following death in utero of a twin foetus, there are three possible terminations; spontaneous abortion of both twins, extrusion of the dead foetus with continuation of the remaining pregnancy, or retention of both, but only the third sequence concerns us here. There appear to be three possible pathological processes which may affect a dead foetus retained in the uterus. ${ }^{74}$ It may undergo maceration. It may become hard and apparently fixed without much flattening or loss of normal body contour, and this hardening rather than softening, that is the exact antithesis of maceration, has been termed mummification. A third possibility is the compression of the foetus into an object resembling parchment. This is the foetus papyraceous in which initial maceration has become arrested by mechanical pressure, and thus some of the foetal structure is preserved, much as flower specimens are preserved by pressing them between pages of a book. Several authorities, however, make no distinction between the last two sequences, contending that the process that produces the foetus papyraceous is identical to mummification. ${ }^{75}$

Whether this distinction be drawn or not, many of the characteristics of the blighted twin phenomenon are known and some of the more important ones may be briefly summarized. Though blighting occurs in the same proportion in monochorial as in dichorial pregnancies, it occurs more often in primiparas when the pregnancy is monochorial. There is a greater degree of blighting in dichorial pregnancies when the mother is between the ages of thirty to thirty-five, or over forty years of age than at any other time either in dichorial or in monochorial pregnancies. ${ }^{76}$ No sex bias has been noticed in blighting, but the surviving twins are heavier than either twin of viable twin pregnancies, ${ }^{77}$ and the viable twin is usually the first born. ${ }^{78}$

The greatest incidence of blighting is from the third through the fifth month. Amniotic fluid is usually absent in the amniotic cavities of foetuses that are flattened and mummified, but a fluid of unknown origin may be present around a mummy which is hard. The position of the foetus in the uterus prior to death may be directly related to the kind of physical modification it experiences, as often the blighted twin becomes compressed between the amniotic sac of the surviving foetus and the uterine wall. ${ }^{79}$ While hydramnios in the amnion of the viable twin may be a factor in the flattening of his dead sibling, it is not the principal one, nor is it a symptom that might indicate with any great probability the early death and retention in the uterus of one or more foetuses. ${ }^{80}$

Although toxaemia of pregnancy occurs in some of the cases, an uneventful course is the rule rather than the exception. It would seem that transitory bleeding may 
afford a possible clue to, and occur as the result of the death of one foetus. It is argued that this symptom may stem from any of a number of causes, and therefore be of no real diagnostic significance, ${ }^{81}$ but some investigators have correlated the arrest in the development of the blighted foetus to the time during the pregnancy when one or more episodes of vaginal haemorrhage were reported. ${ }^{82}$

Clearly, several of the traits of the blighted twin phenomenon match the indications given by Savonarola in his fera account. Most obvious is the fact that in both instances a normal child is born accompanied by a strange aberration. The appearance of the mummified foetus also corresponds to the fera description, for depending on the time in its development the foetus died, it may resemble any of a number of living animals. As mummification is most frequent in foetuses dying between the third and sixth months of intra-uterine life, ${ }^{83}$ the blighted foetus' general structure has been formed, and its ultimate shape depends on the pressures exerted upon it during the time it is retained in the uterus.

An interesting case history has recently been recorded in Sardinia of a triplet gestation where two of the foetuses died at different times and were retained in utero. Five days before the one normal infant was born, the smaller mummified foetus was discharged spontaneously. After the birth of the normal infant, another mummified foetus was discovered lodged in the placenta. The triplets were photographed, and though the viable infant, a male, was undersized, weighing only 1300 grams, the mummified foetuses were very much smaller. The body of the spontaneously discharged foetus, which weighed only 24 grams and measured 12 centimetres, was coloured a muddy-grey, but its head was described as being tinted a brownishyellow, and thus the creature resembled an insect or a small reptile. The third foetus, more fully developed than his mummified twin, measuring 26 centimetres and weighing 182 grams, could easily have been mistaken for a lower animal. ${ }^{84}$

Other features of this case support the argument that the phenomenon Savonarola reported was a series of blighted twin births. The fact that the reporting investigator noted that the forty-three-year-old mother had experienced episodes of metromenorrhagia during her pregnancy is one of these. ${ }^{85} \mathrm{It}$ may be that the copious discharges that Savonarola believed to be characteristic of southern women were instances of vaginal or uterine bleeding during pregnancy. Another supportive observation in the Sardinian case concerns certain variations in the insertions of the three umbilical cords.

Normally, the umbilical cord is inserted eccentrically upon the foetal surface of the placenta, somewhere between the centre and the periphery. A central insertion is rare, but still more uncommon is the junction of the cord near the margin of the placenta. Most unusual, but of great practical significance is the velamentous insertion of the cord, the insertio velamentosa or membranosa. In this condition, the vessels of the cord separate some distance from the placental margin, gain attachment to the chorionic membrane, and divide before they reach the functioning area of the chorion. ${ }^{86}$ The consequences of this anomalous development may be of great importance for if the placenta is inserted in the lower part of the uterus, the velamentous vessels may extend partially across the internal os (vasa previa) and, as dilatation progresses, be injured during delivery. ${ }^{87}$ 


\section{Michele Savonarola and the blighted twin phenomenon}

Velamentous insertion is potentially dangerous to the infant, for rupture of the membranes may also sever a foetal vessel, causing haemorrhage and ultimately exsanguination of the child. ${ }^{88}$ Though rare, insertio velamentosa and its concomitant vasa previa, are more frequently observed in multiple than in single pregnancies, and have been termed almost routine in triplets. ${ }^{89}$ It is not surprising to find, therefore, that in the Sardinian case, the cord of the viable twin was centrally, while those of the other two were velamentously inserted. ${ }^{90}$ In another recent case of the blighted twin phenomenon, the viable infant's cord was velamentously inserted. Had the attending physicians not been able to administer immediately the most modern techniques of neonatal care, the viable twin very likely would have died too. ${ }^{91}$

Therefore, it may be suggested that the death of the viable infant at the time of expulsion which the Apulian women attributed to a lethal property of the fera was caused by post-haemorrhagic anaemia resulting from a rupture of one or more of the foetal vessels during the process of parturition. The women, of course, would not have been able to determine that the bleeding was caused by an injury to the foetal rather than to the maternal uterine vessels, ${ }^{92}$ and they may have found that they could account for the seemingly inexplicable death of an apparently normal newborn child most easily by fixing blame on his animal-like mummified twin.

It is possible then to explain most of the physical characteristics listed by Savonarola in his account of the fera phenomenon by reviewing the newer knowledge acquired concerning the pathological complications that may accompany multiple gestations. If a number of cases had been observed in Apulia where a viable child was delivered with a blighted twin who had been retained in utero, compressed, and mummified, the general conditions would correspond to those reported by the Paduan physician. Furthermore, if, on occasion, the viable twin had died owing to vasa previa, which has one of the highest mortality rates of obstetrical accidents, ${ }^{93}$ then the ostensible assault of the fera upon the foetus could be cogently explained.

Savonarola's interest in and practical experience with obstetrics may appear to impede the establishment of this theory. That a physician who had managed numerous obstetrical cases could mistake an aborted foetus for an animal might at the outset seem absurd, but two facts concerning the man and his profession mitigate this stringent judgment. The first is that Michele Savonarola claimed neither to have witnessed the birth of a fera, nor to have inspected the parturient. The events he reported were based entirely upon the testimony of his father who was not medically trained. The second is that Savonarola, like many physicians before his time and since, sought to explain the unknown by analogy to the known, to interpret traditional observations in light of dicta he accepted as authoritative.

Curiously, in so doing, he provided sufficient data to stimulate, some five hundred years later, a similar endeavour. The tentative reconstruction of a clinical pattern that we are now beginning to understand has been sketched here by combining his evidence and modern findings. This presentation, it is hoped, has demonstrated once more the truth of Giovanni Michele Savonarola's observation that though we are not accustomed to seeing them, many things are true that do not initially seem so. 


\section{Y. V. O'Neill}

\section{REFERENCES}

1. Lynn Thorndike, Science and thought in the fifteenth century, New York, 1929, pp. 1-23.

2. George Sarton, 'Science in the Renaissance', The Civilization of the Renaissance, New York, Frederick Ungar, 1929, pp. 75-95.

3. C. D. O'Malley, Andreas Vesalius of Brussels, Berkeley and Los Angeles, University of California Press, 1964, pp. 1-20.

4. Joseph Needham, $A$ history of embryology, Cambridge, Cambridge University Press, 1959, pp. 95-96.

5. Savonarola's Practica de aegritudinibus a capite ad pedes was first printed at Colle by Bonus Gallus who completed the work on 13 August 1479. This editio princeps of the Practica would seem to be the last book published by the printer, as he is believed to have died shortly thereafter, and, in any event, prior to 4 September 1481, Catalogue of books printed in the fifteenth century now in the British Museum, Part VII, ed. Victor Scholderer, London, British Museum, 1935, p. 1078. Most other early editions of the Practica were published in Venice. Among these are editions of 1486, 1497, $1502,1518,1519,1547,1559,1560$ and 1561. Lynn Thorndike in A history of magic and experimental science, New York, Macmillan, 1934, vol. 4, p. 185 (hereafter cited as Experimental science), referred to a Bolognese edition of 1487, and described a few of the extant manuscript copies of the Practica. The work will be cited henceforth as P.M., and the date of the edition indicated.

6. A portrait of the amiable but scholarly physician, seated before a background of stylized Italian cypress, clad in the robes of an academician, poring over thick tomes, aided by pince-nez perched upon his aquiline nose, is found in a manuscript copy of the Practica, A. 125 of the Biblioteca dell'Archiginnasio, Bologna, as reproduced by Giovanni Carbonelli, Sulle fonti storiche della chimica e dell'alchimia in Italia, Rome, Ist. Naz. Med. Farm., 1925, p. 10, and by Luigi Belloni as the frontispiece in his Il trattato ginecologico-pediatrico in volgare-ad mulieres ferrarienses de regimine pregnantium et noviter natorum usque ad septennium di Michele Savonarola, Milan, Ciba Industria Chemica, 1952, (hereafter cited as Belloni, Il trattato).

7. Though Arnaldo Segarizzi's Della vita e delle opere di Michele Savonarola, medico padovano delle seculo $X V$, Padua, 1900, is still the most authoritative work on Michele Savonarola, it is an extremely rare pamphlet. For that reason, Thorndike, Experimental science, vol. 4, pp. 183-214 devoted a chapter to Savonarola, focusing chiefly upon the physician's writings on physiognomy and baths. Thorndike's section, published almost forty years ago, remains the only major examination of Savonarola's life and works in English.

8. Francesco Pierro, 'Michele Savonarola autore di opere scientifiche in volgare con alcune considerazioni sulla data della sua morte', Atti del XXII Congresso nazionale di storia della medicina, Rome, 1967, pp. 713-718.

9. See 'Diploma del marchese Lionello d'Este a favore di Michel Savonarola-30 giugno 1450', Documento I in Pasquale Villari, La storia di Girolamo Savonarola e de' suoi tempi, Florence, Felice Le Monnier, 1930, vol. 1, appendix pages iii-iv.

10. For a listing of his writings, see Thorndike, Experimental science, vol. 4, pp. 185-189; and Segarizzi, op. cit., pp. 31-47, and 79-85.

11. Belloni, Il trattato, pp. ix $-\mathrm{x}$.

12. An analysis of these two works is in Thorndike, Experimental science, vol. 4, pp. 190 214. An extensive account of Savonarola's treatise on physiognomy is Anne Denieul Cormier, 'La tres ancienne physiognomonie et Michel Savonarole', Biol. méd., 1956, 45: no. hors série, pp. 41-66.

13. Carbonelli, op. cit., pp. 154-158, described some of these details in Savonarola's treatise on alcohol.

14. Belloni in Il trattato, pp. 3-206, edited and published the definitive modern recension of this work.

15. Segarizzi, op. cit., pp. 15 and 65, n. 41. The significance of Savonarola's Practica major 


\section{Michele Savonarola and the blighted twin phenomenon}

was underscored by Max Neuburger in his Geschichte der Medizin, vol. 2, pt. 1, Stuttgart, Enke, 1911, p. 442. Neuburger's short critique of the Practica is in ibid., pp. 506-507. A more extensive analysis of the Practica major is in Alexander Rittmann's Culturgeschichtliche Abhandlungen über die Reformation der Heilkunst, Brünn, 1869 , vol 1, pp. 79-134.

16. 'De dispositionibus memborum generationis in viris', Tractatus VI, Capitulum 20, P.M. (1519), f. 230v.-240r.; P.M. (1547), f. 249r.; and P.M. (1560), f. 239v.-249v. 'De membris generationis in foemellis', Tractatus VI, Capitulum 21, P.M. (1519), f. 240r.260v.; P.M. (1547), f. 260r.-283r.; and P.M. (1560), f. 249v.-271r.

17. Tractatus VI, Capitulum 21, Rubrica 27, P.M. (1519), f. 2552v.-56v.; P.M. (1547), f. $276 v .-277 v$.; and P.M. (1560), f. 265r.-266r.

18. The Hippocratic account is in the first of the two-book work, IYNAIKEInN IPRTON KAI $\triangle \mathrm{EYTEPON}$ in Oeuvres complètes d'Hippocrate, ed. E. Littré, Paris, Baillière, 183961 , vol. 8, pp. 148-151. Galen's description of the syndrome in the fourteenth book of his On the usefulness of the parts of the body, ed. and trans. Margaret Tallmadge May, Ithaca, New York, Cornell University Press, 1968, vol. 2, pp. 633-634 (henceforth cited as May edition), and in Opera Omnia, ed. Carolus Gottlob Kühn, Leipzig, C. Cnobloch, 1821-1833, vol. 4, pp. 167-168 (henceforth cited as Kühn edition), resembles the Hippocratic account in several respects. Pliny's mention of the ailment is brief in Caius Plinius Secundus, Naturalis historiae libri triginta septem, Book VII, Chap. 15, Paris, 1524, f. 90, 1. 50. More comprehensive descriptions of the symptom complex are in the third book of Soranus' Gynecology in Sorani Gynaeciorum libri IV, ed. Johannes Ilberg, Corpus medicorum Graecorum, Leipzig and Berlin, 1927, pp. 116-118 (henceforth cited as CMG, IV), and in Soranus' gynecology, trans. Owsei Temkin et al., Baltimore, Johns Hopkins Institute of the History of Medicine, 1956, pp. 158-161 (henceforth cited as Temkin edition), and in the third of the Seven books of Paulus Aegineta, trans. Francis Adams, London, Sydenham Society, 1844, vol. 1, pp. 630-631 (henceforth cited as Adams edition). Paul of Aegina's account of the syndrome is also available in the edition of the tenth-century version of the third book of his writing, Pauli Aeginetae Libri Tertii interpretatio Latina Antiqua, ed. J. L. Heiberg, Leipzig, Teubner, 1912, p. 185 (henceforth cited as Heiberg edition). An analytic review of the various ancient descriptions of this gynaecological complaint is in Johann Lach's 'Die Gynäkologie des Soranus von Ephesus', Samml. klin. Vortr., begr. von Richard von Volkmann, N. F. 335, Leipzig, 1902, pp. 729-730.

19. Gerardus Bituricensis, Glossae super Viatico, Wellcome Library MS, 305, f. 41r; Commentarium magistri Bernardi provincialis super tabulas Salerni in Collectio Salernitana, ed. Salvatore de Renzi, Naples, 1859, vol. 5, p. 289; Gilbert of Aquila, Compendium medicinae, Lyons, 1510, f. ccxciiiir; Bernard of Gordon, Lilium medicinae, Tractatus VII, cap. 18, Venice, 1469, f. 219v. I owe most of this information to the kind direction of Dr. Charles H. Talbot, Research Scholar of the Wellcome Institute for the History of Medicine and of the University of London. Dr. Talbot's encouragement and assistance in the completion of this paper is most gratefully acknowledged.

20. The first Arab scholar to mention Aristotle's zoological works may have been al-Kindi (d. 850), but the first to cite Aristotle's zoology as a source seems to have been al-Jāhiz (d. 869), according to H. J. Drossaart-Lulof's statement in the introductory material to J. Brugman's and his Aristotle-generation of animals-the Arabic translation commonly ascribed to Yayhā ibn al-Batríq, Leiden, E. J. Brill, 1971, p. 40. Many scholars, including D. M. Dunlop, 'The translations of al-Bitriq and Yahyā (Yuhannā) b. alBitriq', J. R. Asiat. Soc., 1959, pp. 141-145, 'abdurrahmān Badawi, La transmission de la philosophie grecque au monde arabe, Paris, 1968, pp. 81-82, and at one time, even H. J. Drossaart-Lulofs, 'Aristoteles Arabus', in Aristoteles in neueren Forschung, ed. Paul Moraux, Darmstadt, 1968, pp. 407, 411-417, have maintained that the Kitäb al-hayāwān was translated into Arabic from a Syriac text by Yahyā ibn al-Britiq during the caliphate of al-Ma'mūn (813-833). This traditional view is currently under 


\section{Y. V. O'Neill}

attack. Though F. E. Peters in his Aristoteles Arabus, Leiden, E. J. Brill, 1968, pp. 47-48, cited the description of the Kitäb al-hayāwän in al-Nadim's famous catalogue, al-Fihrist, where the translation is ascribed to ibn al-Bitriq, Peters noted that the translator has not yet been definitely identified. G. Endress, in his Die arabische Ubersetzungen von Aristoteles' Schrift de Caelo, Frankfurt, 1966, pp. 114-115, after comparing various fragments of the Kitäb al-hayāwän with authentic translations by Yahyâ ibn al-Bitrîq, concluded that the translator did not render Aristotle's zoology. Endress' further suggestion that the version was prepared by Ustât, who translated other Aristotelian works, has been challenged by Drossaart-Lulofs. In contrast with his earlier opinion, expressed in the article written eight years before, but published in the work edited by Paul Moraux in 1968 and cited above, Drossaart-Lulofs now maintains that though the translation we know was not rendered by Yahyâ ibn al-Bitrîq, the present state of knowledge is insufficient to definitely establish the identity of the translator who did render Aristotle's zoological writings into Arabic, see Brugman and Drossaart-Lulofs, op. cit., pp. 2-10.

21. Among the authorities who have expressed this opinion are D'Arcy Wentworth Thompson, preface, Historia animalium in The works of Aristotle, ed. J. A. Smith and W. A. Ross, Oxford, Clarendon Press, 1908, vol. 4, p. iv.; Richard Cresswell, preface, in Aristotle's history of animals, London, H. Bohn, 1862, p. ix. Gunnar Rudberg, 'Zur sogenannten zehnte Buche der aristotelischen Tiergeschichte', Skr. K., Human. Vetensksam., Uppsala, 1910-1912, 13: 1-61; and Pierre Louis, Notice, in AristoteHistoire des Animaux, ed. and trans. Pierre Louis, Paris, 1969, vol. 3, p. 150. Paul Gohlke, Aristotles Tierkunde, 2nd ed., Paderborn, 1957, pp. 23-43, however, contended that the tenth book was not only genuine, but eldest among Aristotle's biological writings.

22. F. E. Peters, Aristotle and the Arabs, New York, New York University Press, 1968, pp. 165-168.

23. Explanatory discussions of Aristotle's generative theories are Erna Lesky, Die Zeugungs und Vererbungslehren der Antike und ihr Nachwirken, Abhandlungen der Akademie der Wissenschaften und der Literatur, Geistes- und Sozialwissenschaftlichen Klasse, Mainz, 1950, pp. 1349-1383; Joseph Needham, op. cit., pp. 37-60; and A. L. Peck, preface, in Aristotle-generation of animals, trans. A. L. Peck, London, Heinemann, 1958, pp. xi-xv.

24. Historia animalium, X, Chaps, 6-7, 637b 5-638b 37.

25. Brugman and Drossaart-Lulofs, op. cit., pp. 29-30

26. Historia animalium, X, Chap. 7, 638a 10-25, and cf. De generatione animalium, IV, Chap. $7,775 \mathrm{~b} 25-776 \mathrm{a} 8$.

27. Louis, op. cit., III, p. 153, n. 3.

28. S. D. Wingate, The mediaeval Latin versions of the Aristotelian scientific corpus, with special reference to the biological works, London, Courier Press, 1931, pp. 72-77.

29. Charles Homer Haskins, Studies in the history of mediaeval science, Cambridge, Mass., Harvard University Press, 1927, pp. 279-280; Lynn Thorndike, Michael Scot, London, Nelson, 1965, p. 29; and Wingate, op. cit., pp. 84-85.

30. Avicenna, De animalibus per magistrum Michaelem Scotum de Arabico in Latinum translatus, Venice, c. 1500, Book X, f. 25r. and cf. ibid., Book XVIII, f. 52v.-53v. (hereafter cited as Avicenna, Abbreviatio).

31. Influenced by the Hippocratic 'two seed doctrine', examined and interpreted by Needham, op. cit., pp. 31-37, and by Erna Lesky, 'Die Samtheorien in der Hippokratischen Schriften-Sammlung', Festschrift zum 80 Geburtstag Max Neuburgers, Vienna, W. Maudrich, 1948, pp. 302-307, the Hippocratic author, op. cit., pp. 148-151, and Galen, op. cit., May edition, II, p. 634, and Kühn edition, IV, p. 168, maintained that the pathological condition resulted from the union of abundant menses and defective semen, and therefore was the product of conception. Soranus, in $C M G, I V$, pp. 116-118, and in Temkin edition, pp. 159-160, and Paul of Aegina, in Adams edition, pp. 630-631, and in Heiberg edition, p. 185, considered the object to derive from the 


\section{Michele Savonarola and the blighted twin phenomenon}

same tumorigenic process that produced uterine neoplasms. Pliny, op. cit., Book X, Chap. 64, f. 151, 11. 9-10, held that the mola arose autogenetically, solely of the woman's seed.

32. Of particular interest in this context is the discussion of Giovanni Arcolano, a contemporary of Savonarola who taught at Bologna 1412-27, and then in Padua and Ferrara where he died in 1460 or 1484 . His Practica medica seu expositio vel commentarii in nonum Rhazis ad regem Almansorem, a very popular book during the fifteenth and sixteenth centuries, contains an extensive discourse on the mola uteri, see Joannes Arculanus, Practica, Venice, 1493, f. 1554-1562. For a modern analysis of the discussions of Savonarola's colleagues on this point, see Paul Diepgen's Frau and Frauenheilkunde in der Kultur des Mittelalters, Stuttgart, G. Thieme, 1963, pp. 191-193.

33. Tractatus VI, Capitulum 21, Rubrica 27, P.M. (1519), f. 255v; P.M. (1547), f. 276v; and P.M. (1560), 265r.

34. Avicenna, Canon medicinae, Venice, 1608, Liber III, Fen XXI, Tractatus II, Capitulum 18, p. 939.

35. Avicenna, Abbreviatio, X, f. 25r.

36. "et haec est sententia Avic, $x$, de animalibus cap. de mola", P.M. (1519), f. 255v; P.M. (1547), f. 276v; and P.M. (1560), 265r.

37. De generatione animalium, IV, Chap. 7, 776a 1-15.

38. Giovanni Savonarola, Michele Savonarola's father, was a Paduan wool merchant, see Segarizzi, op. cit., p. 7. If he made this observation while travelling on business in the mezzogiorno, then the locality of the observation may be delineated at least provisionally with more precision. The Tavoliere di Puglia, or those high plains stretching between the Monte Gargano, the Gulf of Manfredonia and the Apennines, had long been famous as a wool-producing area. It is likely, therefore, that it was the wool produced in the Tavoliere di Puglia that attracted Giovanni Savonarola there and provided him with the opportunity of acquiring this fragment of folk wisdom that he, in turn, transmitted to his physician son. It should be noted that in Roman times, the principal city of this area was the town of Arpi, which lay five miles north of the modern Foggia. Although Arpi had ceased to exist by the late Middle Ages, its name lived on as Gerard of Bourges and Bernard of Gordon recounted (see above n. 19) as a synonym for the Frater Salernitanarum and the Frater Lombardorum. It would seem, therefore, that Giovanni Savonarola's observation coincided with a long and distinguished tradition.

39. The interpretation of this line is difficult, and I am grateful to Dr. Max H. Fisch, Professor Emeritus of Philosophy, University of Illinois, Urbana, and Mrs. Fisch, for their rendering of it which appears here.

40. Et hic adverte quoddam verum mulieribus nostris impossibile apparens sed certe ita est. \& quandoque in nostra evenit in civitate, \& mater nostra vidit, a qua habui \& fuit domina fide digna. mulieribus meridionalibus \& australis regionis, et mulieribus multi \& pravi sanguinis ex malitia regiminis accidit quandoque; ut ultra conceptum verum pariant quoddam frustrum carneum secum portans formam animalis vivens [sic], quod dominae feram appellant. \& causa huiusmodi non fuit virtus spermatis primi ipsius viri; quia ex eo iam conceptus est foetus; sed error secundi coitu emissi. cuius error procedit ab influentia constellationis, seu virtutis coelestis, ut 18 animalium Aristoteles. unde in quibusdam partibus Apuliae, ut vidit etiam pater noster, communiter mulieres sic praegnantes pariunt cum foetu feram, quia [sic] bubonem, accipitrem, aquilam, lacertam, \& huiusmodi. \& asserunt illae mulieres, quod quando cum illo foetu oritur bestia, seu fera nobilis, ut accipiter, \& huiusmodi; quod tunc foetus ille ex nobili viro conceptus fuit. quod si fera fuerit rustica; ut bubo, lacerta, \& huiusmodi ex rustico, \& vili homine factus est. \& haec fera quandoque foetum perimit. \& dicitur, quod tanta est proprietas; quod si cadens in terram hora partus mordeat eum statim moritur foetus. haec sunt vera; licet non appareant quoniam talia hic videre non sumus consueti. Tractatus VI, Capitulum 21, Rubrica 27, P.M. (1519), f. 255v-256r; P.M. (1547), f. 276v.-277r; 


\section{Y. V. O'Neill}

and $P . M$. (1560), f. 265r. If rendered literally, the phrase, "cadens in terram' appears to indicate that Savonarola knew or presumed that the Apulian women delivered their children in a sitting or squatting position, and that therefore, at birth, the child actually fell to earth or to the awaiting hands of the midwife. Savonarola advocated the vertical posturing of the parturient over the now conventional horizontal one, and designed an obstetrical chair to facilitate such deliveries. See Belloni, Il trattato, pp. 120-121.

41. For an analysis of the importance of astrology to surgery and medicine during the fifteenth century see Thorndike, Experimental science, IV, pp. 132-149.

42. De generatione animalium, IV, Chap. 10, 777b 1-778a 10.

43. Ibid., IV, Chap. 7, 775b 25-776a 8. This association is missing also from the two Latin versions of that passage available to Savonarola, the translation of Aristotle's zoological works rendered from the Arabic text by Michael Scot, see above, n. 28, and the recension translated from Greek by William of Moerbeke during the last half of the thirteenth century. As the text of Michael's work is as yet unpublished, the passage in question was compared in two thirteenth-century manuscript copies of the text; Cambridge, Gonville and Caius College, MS. 109, f. 102v.-103r., and a copy in the private library of Mr. Robert B. Honeyman, Jr., of San Juan Capistrano, California, Honeyman MS. 88, f. 113v. Mr. Honeyman's continued interest in this paper, as well as his kindness in permitting me to consult and photograph pertinent pages of his manuscript, are most gratefully acknowledged. A recent edition of part of William's version, De Generatione Animalium translatio Guillelmi de Moerbeke, ed. H. J. Drossaart-Lulofs, Bruges-Paris, Desclée de Brouwer, 1966, where the account of the mola uteri appears on p. 148, facilitated examination of that text. For an analytical comparison of the two versions, see Martin Grabmann's 'Guglielmo di Moerbeke, O.P., il traduttore delle opere di Aristotele', Miscellanea Historiae Pontificiae, XI, n. 20, Rome, Pontifica Università Gregoriana, 1946, pp. 119-127.

44. Historia animalium, $X, C$ ap. 7, 638a 10-25. The renderings of that passage by Michael Scot and by William of Moerbeke were also examined, but again no suggestion of astrological influence was found in either. The relevant lines in these two translations were compared in the edition of the Latin versions of the tenth book prepared by Rudberg. For Michael Scot's version, see Rudberg, loc. cit., pp. 118-119, and for the account in William's recension, see ibid., pp. 134-135.

45. 'Et causa mola matricis est corruptio digestionis et dissolutio caloris', Avicenna, Abbreviatio, XVIII, f. 53v.

46. Giuseppe Pitrè, Sicilian folk medicine, trans. Phyllis H. Williams, Lawrence, Kansas, University of Kansas Press, 1971, pp. 109-110.

47. Tractatus VI, Capitulum 21, Rubrica 25, P.M. (1519), f. 255r.; P.M. (1547), f. 276r; P.M. (1560), f. 264v.

48. Ibid., cf. Avicenna, Canon, Liber III, Fen XXI, Tractatus II, Capitulum 17, p. 930.

49. Cay Lienau reviewed these accounts in his 'Die Behandlung und Erwahnung von Superfetation in der Antike', Clio Med., 1971, 6: 275-285.

50. Edward C. Hughes (ed.), Obstetric-gynecologic terminology, Philadelphia, Lippincott, 1972, p. 467.

51. De generatione animalium, IV, Chap. 5, 773b 14-16.

52. Historia animalium, VII, Chap. 4, 585a 5-14. Pliny reached the same conclusion by presenting identical evidence, 'sed ubi temporis inter duos conceptus intercessit, uterque est perfectus, ut in Hercule et Iphicle fratre eius apparuit . . ', Caius Plinius Secundus, op. cit., VII, Chap. 11, f. 89, 1. 43-44.

53. Arthur William Meyer, 'The occurrence of superfetation', J. Amer. med. Ass., 1919, 72: 769-774; William E. Studdiford, 'Is superfetation possible in the human being?', Amer. J. Obstet. Gynec., 1936, 31 : 845-855; Bryan C. Murless and F. L. McLaughlin, 'Does superfoetation occur?', Br. med. J., 1937, i; 1309-1311; W. Eicher, '72 ägige Geburtspause bei Zwillingen', Münch. med. Wschr., 1970, 112: 422-425. 


\section{Michele Savonarola and the blighted twin phenomenon}

54. 'Quia dictum est tempore impraegnationis os matricis ita claudi, quod punctus acus ingredi non potest ... ut experientia manifestat, fit superimpraegnatio et licet os matricis claudatur; tamen delectatione novi spermatis aperitur, et ipsum deglutit; ut stomachus, qui clausus est super cibum, delectatione adveniente novi cibi aperitur,' Tractatus VI, Capitulum 21, Rubrica 25, P.M. (1519), f. 255r; P.M. (1547), f. 276r; P.M. (1560), f. $264 v$.

55. ' . . et tales habent foetum primum debilem, et etiam secundum', ibid.

56. 'Famula quaedam ab hero suo compressa, ut culpam tegeret Septembri mense Londinum advolet. ubi clanculum peperit; et firmata valetudine, domum reversa est. Decembri autem sequente; novo partu (nam superfoetaverat) occultatum antea crimen divulgavit', William Harvey, Exercitationes de generatione animalium quibus accedunt quaedam de partu: de membranis ac humoribus uteri; et de conceptione, London, 1651, p. 261.

57. Illustrative cases of superfoetation in animal gestations are Heinz Rollhäuser, 'Superfetation in a mouse', Anat. Rec., 1949, 105: 657-663; Charles E. Short, 'Superfetation in the Burro', J. Amer. vet. med. Ass., 1964, 144: 257-258; J. H. Hoogeweg and E. R. Folkers, Jr., 'Superfetation in a cat', ibid., 1970, 156: 73-75; C. D. Gee, 'A case of superfoetation in the cow', Austr. vet. J., 1971, 47: 179; P. F. Scanlon, 'An apparent case of superfoetation in a ewe', ibid., 1972, 48: 74. Reports of the phenomenon's occurrence in human gestations are Victor Föderl, 'Superfetatio, Ein beweisender Fall', Arch. Gynäk., 1932, 148: 653-673; L. Sussi, 'Ein Fall von Superfoetatio', Med. Klin., 1935, 31: 1334-1336; Alberto Zabaleta Lombana and Jorge Milanès Pernett, 'Embarazo triple-Conjugado-Superfetación', Rev. Colomb. Obstet. Ginec., 1964, 15: 73-81 ; G. Robinet, C. Pia, and H. Ezes, 'Sur un cas de superfoetation', Bull. Féd. Soc. Gynec. Obstet. langue franc., 1970, 22: 451-453; and John Fontana and Gilles R. G. Monif, 'Superfetation', Obstet. Gynec. 1970, 35: 585-588.

58. G. E. Abraham, J. R. Marshall and T. A. Daane, 'Disorders of ovulation', in Pathophysiology of gestation, ed. Nicholas S. Assali and Charles R. Brinkman, New York and London, Academic Press, 1972, vol. 1, p. 40.

59. A. F. Clift, F. A. Glover and G. W. Scott, 'Rheology of human cervical secretions', Lancet, 1950, i: 1154-1155; Ludwig Neuhaus, 'Die biologischen Voraussetzungen einer Superfetation der Frau', Beilag. Zt. Geburtsh., 1954, 14: 56-62; Val Davajan, Robert M. Nakamura and Khalil Kharma, 'Spermatozoan transport in cervical mucous', Obstet. gynec. Surg., 1970, $25: 1-43$.

60. Bruce Williams, 'An unusual case of twins', J. Obstet. Gynaec. Br. Emp., 1953, 60: 319-321; and M. Vandeplassche, 'The physiological explanation of split parturition in the pig and other mammalian species', Ann. Endocrin., 1969, 30: 328-341.

61. Nicholson J. Eastman and Louis M. Hellman, Williams' obstetrics, 13th ed., New York, Appleton, Century \& Cross, 1966, p. 664.

62. James Parsons, 'The Crounian Lectures on Muscular Motion for the years MDCCXLIV and MDCCXLV read before the Royal Society', Phil. Trans. R. Soc. Lond., 1745, p. 79.

63. John Archer, 'Observations showing that a white woman by intercourse with a white man and a Negro may conceive twins, one of which shall be white and the other a mulatto', Med. Rep., 3rd hexade, vol. 1, 1810, pp. 322-323.

64. K. Landsteiner's initial identification of three basic blood types in his 'Uber Agglutinationserscheinung normalen menschlichen Blutes', Wien. klin. Wschr., 1901, 14: 1132-1134, was later expanded by Jan Janský in his 'Haematologické studie u psychotiku (Études hématologiques dans les malades mentales)', Sbornik Klinický, 1907, 8: 85-139 (abstract in German in Folia serologica, 1909, vol. 3, p. 316 and résumé in French in J. Immunol., 1931, 20: 136), and W. L. Moss in his 'Studies on isoagglutinins and isohemolysins', Johns Hopk. Hosp. Bull., 1910, 21: 63-70, who completed the classification of four blood groups.

65. Felix Bernstein's 'Ergebnisse einer biostatischen zusammenfassenden Betrachtung über die erblichen Blutstrukturen des Menschen', Klin. Wschr., 1924, 2: 1495-1497, and K. Landsteiner and P. Levine's 'On the inheritance and racial distribution of 


\section{Y. V. O'Neill}

agglutinable properties of human blood', J. Immunol., 1930, 18, 87-94, are important fundamental articles on the subject. An extensive analysis of the development of knowledge concerning blood typing, written with historical perspective, is Hugh Francis Brewer's 'The blood groups', in Blood transfusion, ed. Geoffrey Keynes, Baltimore, Williams \& Wilkins, 1945, pp. 211-330.

66. Hermann Eberle, 'Ein Fall von Superfecundatio', Arch. Gynäk., 1958, 191 : 45-56.

67. G. K. Döring, 'Uber einen Fall von Superfekundatio', Zbe. Gynäk., 1960, 82: 629-633.

68. Eberle, loc. cit., p. 55 cf. Döring, loc. cit., pp. 632-633, and W. R. Mayr, 'Serologische Befunde an viereiigen Vierlingen', Wien. klin. Wschr., 1969, 81: 687-689.

69. Edmund R. Novak and J. Donald Woodruff, Novak's gynecological and obstetric pathology, 6th ed., Philadelphia, W. B. Saunders, 1967, pp. 149-225. The expert advice and helpful suggestions of Doctor Hans Simmer, Professor of Medical History, and of Obstetrics and Gynecology, University of California Medical Center, Los Angeles, in the medical sections of this paper is most gratefully acknowledged, as is his continued interest in its preparation.

70. George Clark Mosher, 'Report of a case of fetus papyraceous with a twin pregnancy', Amer. J. Obstet., 1918, 79: 288-290.

71. James E. Kindred, 'Twin pregnancies with one twin blighted', Amer. J. Obstet. Gynec., 1944, 48: 642-682.

72. Equinn W. Munnell and Howard C. Taylor, 'Complications and fetal mortality in 136 cases of multiple pregnancy', ibid., 1946, 52: 588-597.

73. W. G. Mills, 'Pathological changes in blighted twins', J. Obstet. Gynaec. Br. Emp., 1949, 56: 619-624.

74. A classical account of foetal retention in the uterus is Max Graefe's 'Uber Retention des menschlichen Eies nach dem Fruchttod', Arbeiten aus dem Gebiete der Geburtschilfe und Gynaekologie zur Feier Professor Dr. Carl Ruge, ed. C. Gebhard, Berlin, 1896, pp. 38-79. A shorter but more recent consideration of the problem is Lars Bengtsson's 'Missed abortion-the aetiology, endocrinology, and treatment', Lancet, 1962, i: 339-343.

75. Mills, loc. cit., p. 619.

76. Kindred, loc. cit., pp. 653-657.

77. Ibid., pp. 658 and cf. Edith L. Potter and Allan B. Crunden, 'Twin pregnancies in the service of the Chicago Lying-in Hospital', Amer. J. Obstet. Gynec., 1941, 42: 871-872, and Alan F. Guttmacher and Schuyler G. Kohl, 'The fetus of multiple gestations', Obstet. Gynec., 1958, 12: 535-536.

78. Karl Beierlein, 'Twin papyraceous fetuses in triplet pregnancy', Amer. J. Obstet. Gynec., 1930, 21: 101.

79. Eastman and Hellman, op. cit., p. 664.

80. Kindred, loc. cit., p. 666.

81. Beierlein, loc. cit., p. 102.

82. D. J. Sabath, L. C. Kvitek, and A. H. Baugher, 'Fetus papyraceous in binovular twin pregnancy', Amer. J. Obstet. Gynec., 1948, 54: p. 990; Samuel L. Siegler, 'Triplet pregnancy with papyraceous fetus', ibid., 1937, 34: 1023-1025; and P. Strassmann, 'Die mehrfache Schwangerschaft', Handbuch der Geburtshülfe, ed. von Winckel, Wiesbaden, 1904, vol. 1, p. 781.

83. Beierlein, loc. cit., p. 103.

84. A. Esposito, 'Singolare caso di gravidanza trigemina con due feti mummificati', Clin. Ostet. Ginec., 1963, 65: 537-544. Permission to reproduce the photograph which first appeared in Doctor Esposito's article was graciously granted by the editors of Patologia e Clinica Ostetrica e Ginecologia, and a copy suitable for reproduction was provided by the Photographic Service of the National Library of Medicine.

85. Ibid., p. 538.

86. J. Edgar Morison, Foetal and neonatal pathology, 3rd ed., London, Butterworth, 1970, p. 51 . 


\section{Michele Savonarola and the blighted twin phenomenon}

87. Kurt Benirschke and Shirley G. Driscoll, The pathology of the human placenta, New York, Springer, 1967, pp. 20-25.

88. Before the development of transfusion techniques, exsanguination resulted inevitably in the death of the infant, as was recounted by Ludwig Knapp, 'Eineiige Zwillingsplacenta; velamentöse Insertion; Verblutung beider Früchte unter der Geburt', Arch. Gynäk., 1896, 51: 586-594; and by Eugen Peiser, 'Verblutungstod der Frucht unter der Geburt infolge Ruptur einer Umbilicalarterie bei Insertio velamentosa', Mschr. Geburtsh. Gynäk., 1896, 8: 619-624.

89. Kurt Benirschke, 'Major pathologic features of the placenta, cord and membranes', Proceedings of the Symposium on the Placenta, 1965, 1: 57, and W. Edward Torrey, Jr., 'Vasa Previa', Amer. J. Obstet. Gynec., 1952, 61 : 147.

90. Esposito, loc. cit., p. 539. The three insertions are apparent in the photograph.

91. G. F. Ottolenghi-Preti, 'Sopra un rarissimo caso di gravidanza gemellare con un feto papiraceo e con inserzione velamentosa del funicolo del feto vivo', Ann. Ostet. Ginec., 1972, 93: 173-199. Appended to this article, ibid., pp. 192-199, is the most extensive recent bibliography on the blighted twin and the foetus papyraceous phenomena as well as a listing of cases describing velamentous insertion.

92. Positive diagnosis of the condition is still difficult without a smear preparation of the blood. Such a test reveals the presence of foetal blood elements, normoblasts or nucleated red cells that indicate foetal bleeding, see Torrey, loc. cit., p. 148, and Henry N. Kirkman and Harris D. Riley, Jr., 'Posthemorrhagic anemia and shock in the newborn due to hemorrhage during delivery', Pediatrics, 1960, 24: 92-96.

93. Torrey, loc. cit., p. 148. 